\title{
Survey of Relationships Between Rainfall Rate and Radar Reflectivity in the Measurement of Precipitation
}

\author{
Glenn E. Stout and Eugene A. Muelier \\ Illinois State Water Survey, Urbana
}

(Manuscript received 22 December 1967, in revised form 4 March 1968)

\begin{abstract}
Numerous investigations have been made in the last two decades from both a direct measurement of the radar reflectivity and the rainfall amount, as well as indirect measurements of the raindrop size spectra. Calculations of the reflectivity factor and rainfall rate from these spectra can be made and the relationships determined. Both methods are discussed and a summary of the relationships presented.

These relationships show differences in excess of $500 \%$ in rainfall rate at the same reflectivity. These large differences are primarily associated with differences in geographic locality. In addition, there are smaller differences on the order of $150 \%$ that can be attributed to different types of rain or different synoptic conditions.

Some data are available which are indicative of the differences in the relationship on a given day, depending upon the location within the storm which is sampled. This is briefly described and in only one case out of 18 is there a significant difference.

Estimates of the effects of evaporation, accretion and coalescence on the relationship are made and show some of the reasons for the differences in the relationships noted at different geographical locations. The accuracy of the relationships is investigated with attention directed to the evaluation of total storm amounts. It is shown, in general, that the relationships introduce less uncertainty than the uncertainty in obtaining a radar measurement of the reflectivity.
\end{abstract}

\section{Introduction}

Many radar users have found problems in making quantitative measurements of rainfall. In Alaska, radar operators report that the reflectivity is high for light to moderate rainfalls. In hurricanes, the reflectivity is low while the rain rate is high. In the early 1950's even though radar meteorologists were working with $3.2-\mathrm{cm}$ radar equipment and concerned about the attenuation factor, it was evident that the radar-rainfall relationships changed from day to day and season to season and that these changes were much greater than the attenuation losses.

Since that time a number of investigators have determined $Z-R$ relationships. The authors with the support of the U. S. Army have conducted raindrop spectra measurements at a number of locations. The results of these investigations are presented in this paper. Two different approaches to determination of a relationship have been recognized. These are a direct approach which consists of simultaneously measuring the rainfall rate by rain gages and the radar reflectivity by radar, and an indirect approach of measuring the raindrop spectra and calculating both parameters from the spectra. The advantages and disadvantages of the two methods are discussed in this paper. In addition, it is hoped that by presenting the relationships in one location, a more efficient utilization of the relationships can be made by the radar meteorologist.
Basic to any measurement of precipitation by means of a radar is some form of a relationship between radar parameters and rainfall rate. The rainfall rate and the reflectivity factor are both functions of the raindrop size distribution. In the United States the radar meteorologist has informally adopted a unit called reflectivity factor and designated the symbol $Z$ to represent this quantity. Some investigators have referred to $Z$ as the reflectivity. Some confusion has arisen as the radar engineer uses reflectivity to represent a slightly different quantity. The backscattering cross section of an object is defined as the area which intercepts an amount of power in the incident beam which, if radiated isotropically, would yield a reflected signal strength at the transmitter of the same magnitude as the actual object produces. The radar engineer's definition of reflectivity is the average sum of the radar backscattering cross section per unit volume of space. It can be noted that the dimensions of this quantity is per unit length. The radar meteorologist frequently uses Rayleigh's scattering law and removes the constants of wavelength and refractive index, leaving a term of diameter of the sphere to the sixth power. If the sum of the diameters to the sixth power of the raindrops per unit volume (i.e., the reflectivity factor) is multiplied by the constants of wavelength and refractive index, the normal reflectivity used by radar engineers results. Common usage as introduced into the literature by Marshall 
et al. (1947) has been to call the value of $\Sigma D^{6}$ the reflectivity $Z$. Thus, to avoid this confusion we will speak of $Z$ as the reflectivity factor. 'The common units of $Z$ are $\mathrm{mm}^{6} \mathrm{~m}^{-3}$. Most work has been directed toward the relationship between $Z$ and rainfall rate $R$. form

The $Z-R$ relationships are generally reported in the

$$
Z=A R^{b}
$$

Many investigators have noted a tendency for departures in the data from the familiar Marshall-Palmer $Z-R$ relationship. Some confusion has arisen from this relationship because of uncertainty as to which variable is treated as independent in the original analysis. For the use of the radar meteorologist who wishes to predict the rainfall rate from measurement of the radar reflectivity, the reflectivity should be treated as the independent variable. If the rainfall rate is considered the independent variable, the exponent is smaller and the coefficient larger for the same data.

\section{Direct measurement of the relationship between radar reflectivity and rainfall rate}

One method for obtaining a relationship between the radar backscattering cross section and the rainfall rate is to actually measure both simultaneously. This obvious method has been attempted by several groups (Austin, 1964; Marshall et al., 1947; Hudson et al., 1952) with varying degrees of success. There are a number of disadvantages of such a straightforward method. The fact that the radar invariably samples rain aloft, and the rain gage samples the rain at the surface is one difficulty in the procedure. Austin and Williams (1951) attempted to minimize this error by directing the radar beam directly over a rain gage located on a high point of ground. The radar antenna was directed as low as possible without any ground return showing at the range of the rain gage. Most investigators have attempted to compensate for the time of fall of the raindrops by applying a time lag to the radar observations.

A second problem associated with the elevated radar sample is the horizontal drift of the raindrops during their fall from the radar beam location to the ground. In order to reduce these errors a network of rain gages has been utilized by some groups so that the drift and time lags could be incorporated in the analysis. These methods certainly tend to increase the confidence of the experiment, but there remains considerable doubt whether the errors due to time lag and drift can be completely eliminated by these techniques.

A further disadvantage is the immense discrepancy between the sizes of the samples. Neglecting the vertical extent of the radar beam (this amounts to a loss in the time resolution) and assuming common radar parameters of $1^{\circ}$ horizontal beamwidth and $1 \mu$ sec pulse width, the radar at $10 \mathrm{~km}$ samples a volume over an area of about $2.6 \cdot 10^{4} \mathrm{~m}^{2}$. The rain gage samples an area on the order of $7 \cdot 10^{-2} \mathrm{~m}^{2}$. As the range increases, the radar area is increased proportionately.

To reduce this difficulty one may use more than one rain gage under a radar volume, as was done by Dimaksian et al. (1962). They used three networks at ranges of 12,22 and $32 \mathrm{~km}$ with 5,9 and 12 gages all located within their respective radar areas. This yielded a gage density of one gage per $0.04,0.045$ and $0.05 \mathrm{~km}^{2}$, respectively. Thus, the measurement of the radar $Z$ could be related to the average rainfall rate from the average of at least five gages. Unfortunately, the calibration results of this work have beeen directed toward the calibration of a particular radar in terms of deflection of an A scope. Without specific knowledge of the receiver and detector characteristics, it is not possible to use these results elsewhere. The authors were surprisingly successful as shown in a later paper (Dimaksian and Zotimov, 1965), where they report that "when the radar installation is sufficiently sensitive to rainfall intensity, the estimate of total precipitation in an area will be more accurate than could be obtained from a rainfall measuring network of practically any density."

Doherty (1963) performed a unique direct measurement which permitted a high confidence in the measurement of the radar scattering. In this experiment the receiver was separated from the transmitter by $860 \mathrm{~m}$, and measurements of the direct transmission between antennas made it possible to eliminate the need for knowing precisely the transmitter power and gain of the receiving and transmitting antenna. His results shown in Table 1 indicate a much lower coefficient than that ordinarily found. $\mathrm{He}$ found higher $A$ 's as the rainfall rate increased. His Doppler frequency records indicated downdrafts on a number of occasions before the onset of rain. This would account for the low $A$.

Wilson (1963), using data from a $1100-\mathrm{mi}^{2}$ rain gage network, obtained $Z-R$ relationships for a number of thunderstorms in Oklahoma. His procedure consisted of obtaining the best relationship, using least squares method, between network average amounts from the radar and network average amounts from rain gages. In 4 of the 6 storms analyzed, his $Z-R$ relationships did not depart significantly in terms of his measurement error from the frequently quoted, $Z=200 R^{1.6}$.

Caton (1964) used a Doppler radar in conjunction with a rain gage to deduce the drop size spectra. The rain gage provided an average water flux at the ground level and the radar provided a frequency power spectrum. The drop size spectra were deduced from these two measurements, and the reflectivity factor and rainfall rates were calculated from this spectrum. He found little change of $Z(1 \mathrm{db})$ between the melting level and a $Z=240 R^{1.3}$ in rain near the cloud base. Other investigators (Berjuljev et al., 1966; Aoyagi, $1964)$ in USSR and Japan have reported $Z-R$ relations from radar measurements. Results are within the range already shown. These differences, which may be due 
TABLE 1. Radar reflectivity, rainfall rate relationships from direct measurement.

\begin{tabular}{|c|c|c|c|c|c|c|}
\hline Investigator & $\begin{array}{l}\text { Geographical } \\
\text { location }\end{array}$ & $\begin{array}{c}\text { Range of } \\
\text { applicability* }\end{array}$ & & $R^{b}$ & $\begin{array}{l}\text { Accuracy } \\
\text { estimate } \\
\text { (standard } \\
\text { deviation, db) }\end{array}$ & Comments \\
\hline Doherty (1963) & Ottawa, Canada & $\begin{array}{c}\text { TRW } \\
\text { not TRW } \\
R<10 \\
R<20 \\
R<40 \\
R<60\end{array}$ & $\begin{array}{l}70 \\
38.4 \\
18.6 \\
25.9 \\
33.9 \\
38.2\end{array}$ & $\begin{array}{l}1.42 \\
1.63 \\
2.37 \\
2.02 \\
1.79 \\
1.69\end{array}$ & $\begin{array}{l}2.5 \\
1.7 \\
1.6 \\
1.7 \\
1.9 \\
2.0\end{array}$ & \\
\hline Berjuljew et al. (1966) & Valday, USSR & & 340 & 1.5 & & $\begin{array}{l}\text { The exponent is as- } \\
\text { sumed equal to } 1.5 \\
\text { and the coefficient } \\
\text { determined from } 2 \mathrm{y} \\
\text { of rainfall. }\end{array}$ \\
\hline Wilson (1963) & Norman, Okla. & $\begin{array}{l}\text { TRW } \\
\text { TRW } \\
\text { TRW } \\
\text { TRW }\end{array}$ & $\begin{array}{r}45 \\
241 \\
183 \\
141\end{array}$ & $\begin{array}{l}1.43 \\
1.45 \\
1.18 \\
1.72\end{array}$ & & $\begin{array}{l}\text { Extreme low coefficient } \\
\text { Extreme high coefficient } \\
\text { Extreme low exponent } \\
\text { Extreme high exponent }\end{array}$ \\
\hline Aoyagi (1964) & Tokyo & & 100 & 1.4 & & For diffuse radar echoes \\
\hline
\end{tabular}

* TRW, thunderstorm; $R\left(\mathrm{~mm} \mathrm{hr}^{-1}\right)$.

somewhat to technique or measurement error, are also thought to be real. One cannot model a rainstorm for the entire world.

\section{The relationship between reflectivity factor and rainfall rate from measurements of drop size spectra}

Many problems associated with direct measurement of radar return and rain gage rainfall rates, and comparison of the two results, can be eliminated by direct measurement of the drop size spectra. However, new problems arise. The most serious difficulty with this type of measurement is that the volume in space in which the drops can be sampled is limited to a few cubic meters. The assumption must then be made that these few cubic meters are representative of the $10^{5}$ or $10^{6} \mathrm{~m}^{3}$ sampled by the radar.

A study by Mueller and Sims (1966a,b) indicates that for a sample at $5 \mathrm{ft}$ above ground level, a sample of $44 \mathrm{~m}^{3}$ is required to estimate the rainfall rate to within $10 \%$ with $95 \%$ confidence. It is also demonstrated in the same paper that a smaller volume is adequate to determine the $Z-R$ 'relationship, if an adequate number of samples is included in the analysis. Thus, in this analysis using $1-\mathrm{m}^{3}$ samples, less than $12 \%$ of the variance of data points around the regression line could be attributed to the sample size.

When raindrop size spectra for a volume in space are used to determine the rainfall rate, the velocity of the individual raindrops must be known. Likewise, the calculation of the reflectivity factor from spectra on a horizontal surface requires the velocity of the drops. The nearly universal acceptance of the terminal velocity, reported by Gunn and Kinzer (1949), was used for the velocity of the raindrops. This assumption is probably quite reasonable near the ground, as is evidenced by the generally good agreement between the average rainfall rates from drop size spectra and the rates from a rain gage. However, at the heights sampled by the radar, it is equally certain that the raindrops are not moving with terminal velocity with respect to ground because of the existence of either updrafts or downdrafts. Vertical pointing Doppler radar measurements have confirmed that the drops are moving at velocities with respect to earth that are different than the stagnant air terminal velocities.

Calculations of the radar scattering from the drop size spectra, assuming spherical drops, can be made by either the Rayleigh scattering assumption or from the more complete Mie scattering, depending primarily on the wavelength of the radar under consideration. Since the majority of work is at a wavelength of $3 \mathrm{~cm}$ or longer, the simpler Rayleigh scattering is usually assumed adequate. Rayleigh scattering for $3-\mathrm{cm}$ radiation differs from the Mie scattering by less than $2 \mathrm{db}$ at rainfall rates of $400 \mathrm{~mm} \mathrm{hr}^{-1}$, and the difference is much less at lower rainfall rates.

Table 2 is a list of $Z-R$ relationships as determined from drop size spectra from several different investigators and for different types of rains. Diem's (1966) observations were taken at a number of locations and exhibit a low exponent. Most of the rain was under $12 \mathrm{~mm} \mathrm{hr}^{-1}$. It is not known whether he has used $R$ or $Z$ as the independent variable.

The low coefficient for the orographic rains in Hawaii as first reported by Blanchard (1953) and later by Fujiwara (1967) appear to be in order. The drops in the Hawaiian upslope rainfall are very numerous and quite small, and rainfall rates are low. 
TABLE 2. Radar reflectivity, rainfall rate relationships from drop size spectra.

\begin{tabular}{|c|c|c|c|c|}
\hline Investigator & $A^{Z}$ & $R^{\mathrm{b}}$ & $\begin{array}{l}\text { Standard error } \\
\text { of estimate } \\
\text { of } \log R\end{array}$ & Comments \\
\hline Marshall et al. (1947) & 220 & 1.6 & & Canada, widely accepted and used \\
\hline Blanchard (1953) & $\begin{array}{l}31: \\
16.6\end{array}$ & $\begin{array}{l}1.71 \\
1.55\end{array}$ & & $\begin{array}{l}\text { Orographic Hawaiian rain at cloud base } \\
\text { Orographic Hawaiian rain within the cloud }\end{array}$ \\
\hline Fujiwara (1967) & 80 & 1.38 & & Orographic Hawaiian rain \\
\hline Hardy (1962) & 312 & 1.36 & & 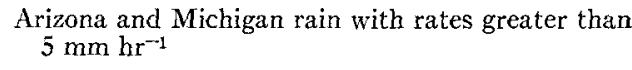 \\
\hline Imai (1960) [Japan] & $\begin{array}{r}700 \\
300 \\
200 \\
80\end{array}$ & $\begin{array}{l}1.6 \\
1.6 \\
1.5 \\
1.5\end{array}$ & & $\begin{array}{l}\text { One day of probably warm rain } \\
\text { One day continuous rain } \\
\text { Air mass showers } \\
\text { Pre-warm front rain }\end{array}$ \\
\hline Diem (1966) & $\begin{array}{l}184 \\
278 \\
240 \\
176 \\
151 \\
179 \\
227 \\
178 \\
150 \\
137\end{array}$ & $\begin{array}{l}1.28 \\
1.30 \\
1.30 \\
1.18 \\
1.36 \\
1.25 \\
1.31 \\
1.25 \\
1.23 \\
1.36\end{array}$ & & $\begin{array}{l}\text { Overall average of different locations } \\
\text { Entebbe, Uganda (tropical) } \\
\text { Lwiro, Congo (tropical) } \\
\text { Palma } \\
\text { Barza, Italy } \\
\text { Karlsruhe, Germany, spring } \\
\text { Karlsruhe, Germany, summer } \\
\text { Karlsruhe, Germany, fall } \\
\text { Karlsruhe, Germany, winter } \\
\text { Axel Heiberg Land, }\end{array}$ \\
\hline Foote $(1966)$ & 520 & 1.81 & & Tucson, Ariz. \\
\hline $\begin{array}{l}\text { Dumoulin and } \\
\text { Gogolombles (1966) }\end{array}$ & $\begin{array}{l}730 \\
255 \\
426\end{array}$ & $\begin{array}{l}1.55 \\
1.45 \\
1.5\end{array}$ & & $\begin{array}{l}\text { France, highest coefficient } \\
\text { Lowest coefficient } \\
\text { Average of all observations, } 0.95 \text { correlation } \\
\text { coefficient }\end{array}$ \\
\hline $\begin{array}{l}\text { Mueller and Sims } \\
\quad(1966 \mathrm{a}, \mathrm{b})\end{array}$ & $\begin{array}{l}286 \\
221 \\
301 \\
311 \\
267 \\
230 \\
372 \\
593 \\
256\end{array}$ & $\begin{array}{l}1.43 \\
1.32 \\
1.64 \\
1.44 \\
1.54 \\
1.40 \\
1.47 \\
1.61 \\
1.41\end{array}$ & $\begin{array}{l}0.198 \\
0.170 \\
0.136 \\
0.147 \\
0.142 \\
0.171 \\
0.153 \\
0.175 \\
0.163\end{array}$ & $\begin{array}{l}\text { Florida } \\
\text { Marshall Islands } \\
\text { Oregon } \\
\text { Indonesia } \\
\text { Alaska } \\
\text { North Carolina } \\
\text { Illinois } \\
\text { Arizona } \\
\text { New Jersey }\end{array}$ \\
\hline
\end{tabular}

Dumoulin and Gogolombles (1966) performed an experiment similar to Austin's with a radar directed at low elevation angles over a single rain gage. Additionally, they obtained a number of drop size spectra in the vicinity of the rain gage for which $Z-R$ relationships are reported in Table 2 . These results from the rain gage readings and the radar measurements for identical observation times were compared. In general, they found good agreement between the rainfall rates obtained from drop size spectra and the rain gages. However, when the radar $Z$ was converted to a rainfall rate by means of the spectra-established $Z-R$ relationship, a factor of at least 2 in rainfall rate remains. Dumoulin and Gogolombles also indicated that the $Z-R$ relationship shows a large variation with time during a storm.

\section{Discussion of the relationships and their vari- ability}

It is immediately apparent from examination of Tables 1 and 2 that the constants of the relationships are widely variable. At the extremes one might compare the differences in the $Z$ value at $1 \mathrm{~mm} \mathrm{hr}^{-1}$ between Doherty in Table 1 and Dumoulin's relationships of Table 2. A difference of a factor of $10(10 \mathrm{db})$ exists. If one assumes a measured value of $Z=10^{5}$, the rainfall rates calculated from these two relationships would be different by a factor of 5 . Thus, differences of at least $500 \%$ in heavier rainfall rate exist between these relationships. If one assumes a lower value of $Z$ of $10^{2}$, then it is only a factor of 3 or $300 \%$. It is probable that some of the differences may be partially due to variations in methods of obtaining the relationships. However, considerable differences exist using the same technique as the result of topography, geographical variation, rain type, synoptic type, thermodynamic structure of the atmosphere, evaporation and, to some extent, coalescence.

\section{a. Geographical differences}

Results of studies conducted by Diem and by the staff of the Illinois State Water Survey over a period of 
JUNE 1968

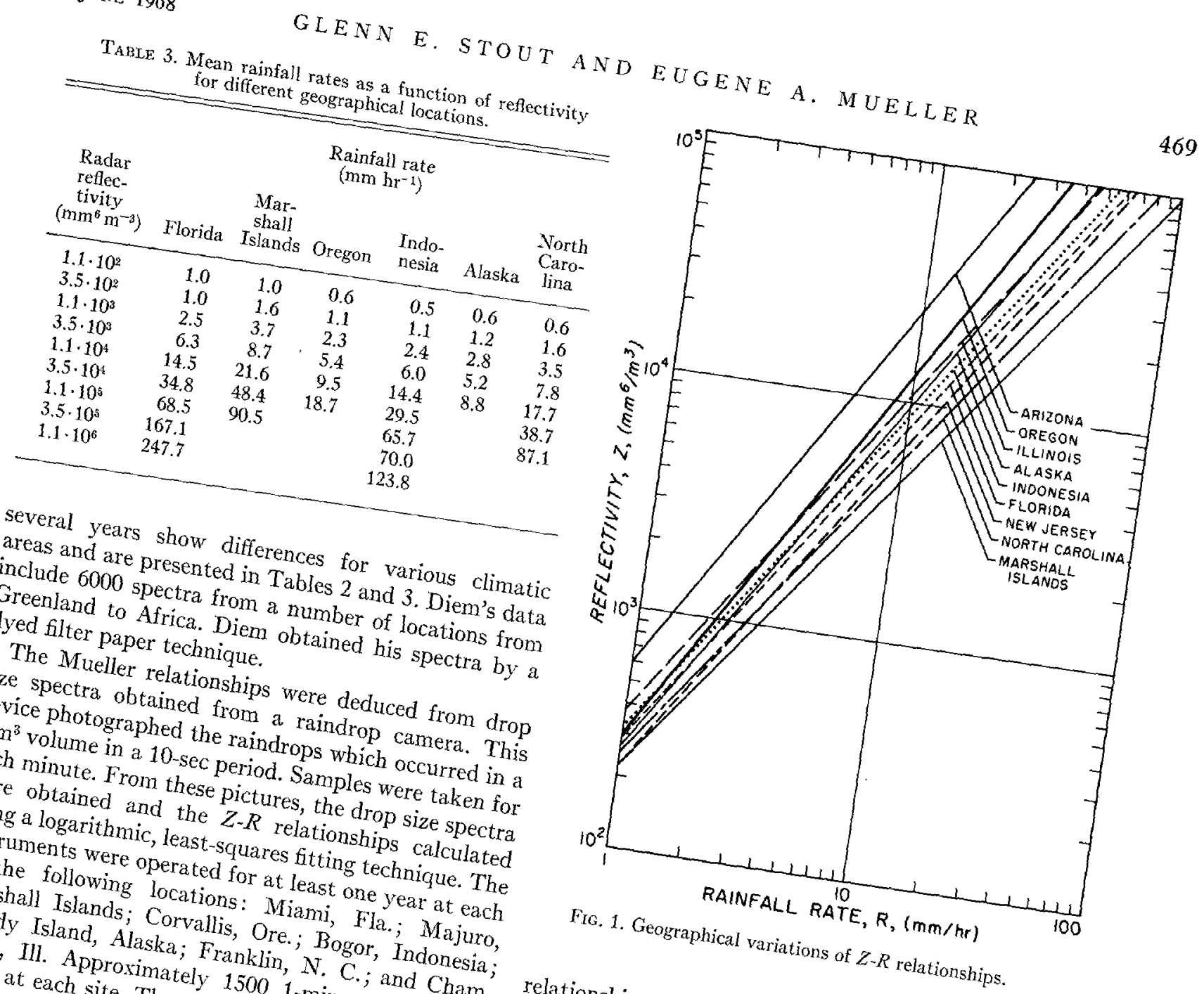

areas and are presented in diferences for various climatic

Greenland spectra from Tables 2 and 3. Diematic dyed filter to Africa. Diem a number of location's data

The paper technique obtained his spections from

size Mueller relation

device photographed from a raindroped from drop each mimue in a 10-sec periodrops which occured This were mimute. From these pictur. Samples were taked in a using obtained and the pictures, the drop taken for instrum a logarithmic, least- $Z-R$ relationships size spectra of the for were operated fuares fitting techniculated Marshall following locations at least one yeaque. The Woody Islands; Corvallis, Miami, Fla. paign, Ill An, Alaska; Frankl. ; Bogor, Indonesuro, taken at each proximately 1500 1 N. C.; and Cham spectra on 621 days. At total sample consistes were The rainfall rate exceeded 25 mi, Bogor and Cha 20,400 sample durin Flagstaff represent $10 \%$ of the Since the July and August. Alaska, the climate of Oregon is Indonesia tend to be are very similar to that of medium values to be nearly the similar. Florida and high ratorida has higher rectivity, but for for low and ditions pres suggests that diffes. This departure high $Z$ these two vail during high diferent meteorolorical the

The two locations. and Alask extreme locarions are conditions at indicate the highest oregon). The $M$ arshall Marshall Islands reflectivity. At a reflectivit rate for a particuland data Island 3 , the rainfall rate of $1.1 .10^{4} \mathrm{~mm} \mathrm{~m}^{6} \mathrm{madar}$ drop size climate is 2.5 times greatring in the $\mathrm{m}^{-3}$ in relatively spectra in the Mareater than in Alaskarshall yield as murge number of Marshall Islands sask. The in the Alach radar return anall droplets which tain a in the Alaskan rains.

collected by the authors.
Diem's data also exhibit large differemined from samples and Entebbe, Uganda, climatic areas. Betwees in the as determinent. This is of a $Z=10^{4}$, a factor of 2 in also be mined by Mueller's same order of of 2 in greatly noted that the relation worlde data magnitude Islands. Bothent from that of and thus Both of these location Mueller for the $M$ is not values of the agreement is reations are in tropical Marshall somewh of the exponents reasonable. In gical regions due in the in part to the choice of theller's data. This to be lations ansis. If Diem chose the independent may be which would yield lower $R$ as independent, variable in b. Diable was selected by Diem as in not clear b. Differences in the relations Diem as independent. At some groups according to the data were separated into
reported by the obin-type classifations, the rain types recognized observer operating classification in and continuous raized were thunderst the camera. The a plot of the $?$ 
TABLE 4. Radar reflectivity, rainfall rate relationships using rain type stratification.

\begin{tabular}{|c|c|c|c|c|c|c|}
\hline Location & Rain type & $A^{Z}$ & $R_{b}^{b}$ & $\begin{array}{l}\text { Correlation } \\
\text { coefficient }\end{array}$ & $\begin{array}{l}\text { Standard } \\
\text { error of } \\
\text { estimate }\end{array}$ & $\begin{array}{l}\text { Minutes of } \\
\text { data }\end{array}$ \\
\hline Florida & $\begin{array}{l}\text { Continuous } \\
\text { Showers } \\
\text { Thunderstorms }\end{array}$ & $\begin{array}{l}322 \\
250 \\
224\end{array}$ & $\begin{array}{l}1.33 \\
1.47 \\
1.51\end{array}$ & $\begin{array}{l}0.94 \\
0.95 \\
0.94\end{array}$ & $\begin{array}{l}0.187 \\
0.185 \\
0.190\end{array}$ & $\begin{array}{l}911 \\
696 \\
902\end{array}$ \\
\hline Marshall Islands & $\begin{array}{l}\text { Continuous } \\
\text { Showers }\end{array}$ & $\begin{array}{l}226 \\
146\end{array}$ & $\begin{array}{l}1.46 \\
1.42\end{array}$ & $\begin{array}{l}0.97 \\
0.92\end{array}$ & $\begin{array}{l}0.184 \\
0.141\end{array}$ & $\begin{array}{r}1491 \\
952\end{array}$ \\
\hline Oregon & $\begin{array}{l}\text { Continuous } \\
\text { Showers } \\
\text { Thunderstorms }\end{array}$ & $\begin{array}{l}295 \\
327 \\
339\end{array}$ & $\begin{array}{l}1.59 \\
1.66 \\
1.64\end{array}$ & $\begin{array}{l}0.92 \\
0.91 \\
0.95\end{array}$ & $\begin{array}{l}0.133 \\
0.135 \\
0.089\end{array}$ & $\begin{array}{r}600 \\
218 \\
82\end{array}$ \\
\hline
\end{tabular}

some form of weather training and their reports were accepted as filed.

The camera at Franklin, N. C., was operated on the side of a mountain some $4 \mathrm{mi}$ from the observer's normal duty station. This prevented him from making observations of the rain type occurring at the camera. The observers at Alaska reported continuous rain for nearly all of the data, and their reports of rain showers were not sufficient to allow meaningful regressions. At the other extreme, nearly all of the data from Indonesia were reported as thunderstorms. At the remaining locations, stratification by rain type was performed and the results of the logarithmic least squares are shown in Table 4.

Since the standard error for this sorting of the data does not decrease appreciably, this stratification does not benefit the user greatly. It was found that the more showery a rain becomes, the higher the reflectivity factor for medium to high rates. This is indicated by the increase in the size of the exponent from continuous rain through showers to thunderstorms.

\section{c. Stratification by synoptic type}

Stratification of data by examining the surface meteorological chart prepared by the U. S. Weather Bureau was attempted. The classification was in accordance with the major disturbance in the area and its relative position to the sampling point. The classifications include air mass, pre-cold frontal, cold frontal, post-cold frontal, warm front, overrunning, easterly wave, trough aloft, warm occlusion, cold occlusion, trade wind showers, and intertropical convergence zone. Naturally, not all of these classes were filled at any one location. The data from Indonesia could not be stratified because surface maps were not available.

Table 5 presents the results of the synoptic stratifications for several locations. Some improvement is suggested in this stratification scheme. The standard

TABLE 5. Radar reflectivity, rainfall rate relationships using synoptic stratifications.

\begin{tabular}{|c|c|c|c|c|c|c|}
\hline Location & Synoptic class & $A^{Z}=$ & $R_{b}^{b}$ & $\begin{array}{l}\text { Correlation } \\
\text { coefficient }\end{array}$ & $\begin{array}{l}\text { Standard } \\
\text { error of } \\
\text { estimate }\end{array}$ & $\begin{array}{l}\text { Minutes of } \\
\text { data }\end{array}$ \\
\hline \multirow[t]{8}{*}{ Florida } & Air mass & 323 & 1.42 & 0.98 & 0.180 & 467 \\
\hline & Pre-cold front & 280 & 1.49 & 0.95 & 0.188 & 744 \\
\hline & Cold front & 198 & 1.54 & 0.95 & 0.176 & 187 \\
\hline & Warm front & 403 & 1.24 & 0.96 & 0.145 & 341 \\
\hline & Overrunning & 302 & 1.36 & 0.94 & 0.165 & 196 \\
\hline & Easterly wave & 296 & 1.35 & 0.97 & 0.156 & 536 \\
\hline & Trough aloft & 261 & 1.43 & 0.97 & 0.178 & 80 \\
\hline & Pre-cold occlusion & 330 & 1.66 & 0.91 & 0.127 & 40 \\
\hline \multirow[t]{3}{*}{ Marshall Islands } & Easterly wave & 196 & 1.38 & 0.95 & 0.171 & 1126 \\
\hline & Trade wind showers & 126 & 1.47 & 0.98 & 0.130 & 239 \\
\hline & Intertropical convergence zone & 196 & 1.38 & 0.95 & 0.178 & 1136 \\
\hline \multirow[t]{7}{*}{ Oregon } & Air mass & 322 & 1.62 & 0.95 & 0.094 & 157 \\
\hline & Post-cold front & 322 & 1.70 & 0.90 & 0.140 & 204 \\
\hline & Overrunning & 307 & 1.56 & 0.92 & 0.138 & 352 \\
\hline & Warm front & 295 & 1.66 & 0.91 & 0.143 & 158 \\
\hline & Warm occlusion & 339 & 1.48 & 0.95 & 0.126 & 175 \\
\hline & Pre-warm occlusion & 309 & 1.92 & 0.90 & 0.111 & 151 \\
\hline & Post-warm occlusion & 268 & 1.81 & 0.88 & 0.146 & 320 \\
\hline
\end{tabular}


TABLE 6. Radar reflectivity, rainfall rate relationships using thermodynam: instab ility stratification.

\begin{tabular}{|c|c|c|c|c|c|c|}
\hline Location & Instability & $A^{Z}$ & $R^{b}$ & $\begin{array}{l}\text { Correlation } \\
\text { coefficient }\end{array}$ & $\begin{array}{l}\text { Standard } \\
\text { error of } \\
\text { estimate }\end{array}$ & $\begin{array}{l}\text { Minutes of } \\
\text { data }\end{array}$ \\
\hline Florida & $\begin{array}{l}1 \text { (highest) } \\
2 \\
3 \\
4 \\
5 \\
6 \\
7 \\
8 \\
9 \\
10 \text { (lowest) }\end{array}$ & $\begin{array}{l}264 \\
295 \\
307 \\
304 \\
313 \\
206 \\
420 \\
358 \\
352 \\
257\end{array}$ & $\begin{array}{l}1.40 \\
1.36 \\
1.41 \\
1.41 \\
1.39 \\
1.42 \\
1.41 \\
1.31 \\
1.38 \\
1.27\end{array}$ & $\begin{array}{l}0.97 \\
0.97 \\
0.97 \\
0.96 \\
0.98 \\
0.97 \\
0.97 \\
0.95 \\
0.95 \\
0.96\end{array}$ & $\begin{array}{l}0.141 \\
0.169 \\
0.150 \\
0.168 \\
0.141 \\
0.105 \\
0.191 \\
0.155 \\
0.146 \\
0.175\end{array}$ & $\begin{array}{l}136 \\
286 \\
367 \\
416 \\
133 \\
117 \\
161 \\
559 \\
238 \\
167\end{array}$ \\
\hline Marshall Islands & $\begin{array}{l}1 \text { (highest) } \\
2 \\
3 \\
4 \\
5 \\
6 \\
7 \text { (lowest) }\end{array}$ & $\begin{array}{l}153 \\
207 \\
143 \\
234 \\
172 \\
191 \\
166\end{array}$ & $\begin{array}{l}1.38 \\
1.47 \\
1.41 \\
1.36 \\
1.41 \\
1.40 \\
1.46\end{array}$ & $\begin{array}{l}0.97 \\
0.92 \\
0.97 \\
0.92 \\
0.94 \\
0.96 \\
0.96\end{array}$ & $\begin{array}{l}0.182 \\
0.241 \\
0.182 \\
0.250 \\
0.227 \\
0.226 \\
0.218\end{array}$ & $\begin{array}{r}160 \\
303 \\
356 \\
736 \\
738 \\
76 \\
91\end{array}$ \\
\hline Oregon & $\begin{array}{l}1 \text { (highest) } \\
2 \\
3 \\
4 \\
5 \\
6 \\
7 \\
8 \text { (lowest) }\end{array}$ & $\begin{array}{l}237 \\
216 \\
217 \\
211 \\
167 \\
232 \\
263 \\
248\end{array}$ & $\begin{array}{l}1.98 \\
2.01 \\
1.51 \\
1.99 \\
3.05 \\
1.98 \\
1.66 \\
1.90\end{array}$ & $\begin{array}{l}0.86 \\
0.88 \\
0.92 \\
0.86 \\
0.76 \\
0.83 \\
0.88 \\
0.88\end{array}$ & $\begin{array}{l}0.143 \\
0.127 \\
0.136 \\
0.146 \\
0.109 \\
0.160 \\
0.163 \\
0.147\end{array}$ & $\begin{array}{r}32 \\
36 \\
79 \\
369 \\
101 \\
182 \\
99 \\
526\end{array}$ \\
\hline
\end{tabular}

errors do reduce somewhat, and the correlation coefficients generally are slightly higher. Some reduction in the standard error of estimate might be expected as a result of smaller sample. Confidence limits calculated for the exponent $b$ indicate that the chances are remote that these are samples of the same parent population.

\section{d. Stratification by thermodynamic instability}

Next, a measure of the instability of the air was investigated to determine whether a significant reduction of the standard error of estimate could be obtained. The thermodynamic instability to some extent measures the strength of updrafts and available moisture. Tornado forecasts are based partially on this instability. The vigor of the storm might be reflected in the drop size spectra.

A measure of the thermodynamic instability is the amount of energy required to lift a parcel of air from the ground to a prescribed level aloft. If this energy is negative, instability is indicated. In the calculations parcels of air were raised from the surface, and from every $50-\mathrm{mb}$ pressure level to $600 \mathrm{mb}$, up to a pressure height of $150 \mathrm{mb}$. The sum of the energies for each of the parcels is then a measure of the average thermodynamic instability. Radiosonde observations are normally obtained every $12 \mathrm{hr}$. The nearest radiosonde was used for each storm. The range of instabilities was then divided into groups and logarithmic least-square analysis performed on each group.
Table 6 contains the result of this analysis. The standard error of estimate is generally larger for this stratification than for either the synoptic type or the rain type stratification. One of the errors which may contribute to this poor stratification is the time separation between the radiosonde ascent and the time of rainfall. Frequently, the upper air conditions change just before the rain occurs. The inadequacies of the radiosonde data along with the loss of accuracy shown by the standard error of estimate preclude the use of this stratification.

TABLE 7. Radar reflectivity, rainfall rate relationships from different locations within the storm.

\begin{tabular}{|c|c|c|c|c|}
\hline Date & Site & & $\begin{array}{r}A R^{b} \\
b\end{array}$ & Comments \\
\hline 15 May 1963 & $\begin{array}{l}\mathrm{A} \\
\mathrm{B} \\
\mathrm{C}\end{array}$ & $\begin{array}{l}476 \\
430 \\
406\end{array}$ & $\begin{array}{l}1.47 \\
1.45 \\
1.44\end{array}$ & $\begin{array}{l}\text { Light continuous rain with } \\
\text { a maximum rate of } 8.6 \\
\mathrm{~mm} \mathrm{hr}^{-1}\end{array}$ \\
\hline 7 June 1963 & $\begin{array}{l}\text { A } \\
\text { B } \\
\text { C }\end{array}$ & $\begin{array}{l}446 \\
446 \\
433\end{array}$ & $\begin{array}{l}1.40 \\
1.43 \\
1.43\end{array}$ & $\begin{array}{l}\text { Scattered night time con- } \\
\text { vective activity with } \\
\text { showers and thunder- } \\
\text { storms }\end{array}$ \\
\hline 31 July 1963 & $\begin{array}{l}\mathrm{A} \\
\mathrm{C}\end{array}$ & $\begin{array}{l}575 \\
298\end{array}$ & $\begin{array}{l}1.69 \\
1.30\end{array}$ & $\begin{array}{l}\text { Showers and continuous } \\
\text { rain along a stationary } \\
\text { front. Radar indicates } \\
\text { heaviest cell passed over } \\
\text { A. }\end{array}$ \\
\hline
\end{tabular}


TABLE 8. Examples of storm totals using various $Z-R$ relationships.

\begin{tabular}{|c|c|c|c|c|c|c|c|c|}
\hline Location & Synoptic type & $\begin{array}{l}\text { Rain } \\
\text { type* }\end{array}$ & $\begin{array}{l}\text { Maximum } \\
\text { rainfall } \\
\text { rate } \\
\left(\mathrm{mm} \mathrm{hr}^{-1}\right)\end{array}$ & $\underset{(\min )}{\text { Duration }}$ & Actual & $\begin{array}{l}\text { Total } r \\
\text { Synoptic } \\
\text { equa- } \\
\text { tion** }\end{array}$ & $\begin{array}{l}\text { ainfall } \\
\text { Rain } \\
\text { type } \\
\text { equa- } \\
\text { tion** }\end{array}$ & $\begin{array}{l}\text { Marshall- } \\
\text { Palmer } \\
\text { equa- } \\
\text { tion** }\end{array}$ \\
\hline Miami, Fla. & $\begin{array}{l}\text { Air mass } \\
\text { Warm front } \\
\text { Cold front } \\
\text { Easterly wave }\end{array}$ & $\begin{array}{l}\text { TRW } \\
\text { R } \\
\text { TRW } \\
\text { RW }\end{array}$ & $\begin{array}{r}301 \\
43 \\
194 \\
216\end{array}$ & $\begin{array}{r}52 \\
64 \\
63 \\
126\end{array}$ & $\begin{array}{l}65 \\
14 \\
47 \\
46\end{array}$ & $\begin{array}{l}61 \\
17 \\
48 \\
38\end{array}$ & $\begin{array}{l}58 \\
17 \\
49 \\
32\end{array}$ & $\begin{array}{l}45 \\
13 \\
39 \\
26\end{array}$ \\
\hline $\begin{array}{l}\text { Majuro, } \\
\quad \text { Marshall Islands }\end{array}$ & $\begin{array}{l}\text { Intertropical } \\
\quad \text { convergence zone } \\
\text { Tradewind shower } \\
\text { Easterly wave }\end{array}$ & $\begin{array}{l}\text { RW } \\
\text { RW } \\
\text { RW }\end{array}$ & $\begin{array}{l}45 \\
65 \\
88\end{array}$ & $\begin{array}{l}45 \\
45 \\
91\end{array}$ & $\begin{array}{r}4.6 \\
7.8 \\
17\end{array}$ & $\begin{array}{c}3.5 \\
7.7 \\
16\end{array}$ & $\begin{array}{l}3.5 \\
7.1 \\
17\end{array}$ & $\begin{array}{c}2.4 \\
4.3 \\
10\end{array}$ \\
\hline Corvallis, Ore. & $\begin{array}{l}\text { Warm front } \\
\text { Warm occlusion } \\
\text { Cold front }\end{array}$ & $\begin{array}{l}\mathrm{R} \\
\mathrm{R} \\
\mathrm{R} \& \mathrm{RW}\end{array}$ & $\begin{array}{r}6 \\
15 \\
11\end{array}$ & $\begin{array}{r}68 \\
167 \\
116\end{array}$ & $\begin{array}{r}2.3 \\
11.0 \\
4.8\end{array}$ & $\begin{array}{l}2.2 \\
8.9 \\
6.0\end{array}$ & $\begin{array}{l}2.3 \\
9.3 \\
5.5\end{array}$ & $\begin{array}{r}2.8 \\
11.1 \\
7.5\end{array}$ \\
\hline
\end{tabular}

* TRW, thunderstorm; RW, shower; R, continuous rain.

** Italicized entries show best comparison with actual amount.

\section{e. Differences in the relationship within the storm}

Some work was done to determine whether different parts of a storm have significantly different relationships (Sims, 1964). Three raindrop cameras were operated simultaneously. These cameras, referred to as site A, B and $C$, were 0.5 and $1.5 \mathrm{mi}$ apart. Table 7 shows the results for three different days. In general, it was noted that the relationships between the cameras did not depart significantly from each other. On only one day of the 8 cases selected for detailed study could a difference be noted, and data on 10 other days showed small departures. Thus, it would appear that one drop size sampling device to obtain a relationship should be sufficient for any one storm period over an area of $4 \mathrm{mi}^{2}$.

\section{f. Estimates of environmental effects on the relationship}

Very few measurements have been made of the effects of evaporation, coalescence or accretion on the $Z-R$ relationship. Caton (1964) calculated the relationship using Doppler radar measurements under conditions of coalescing of raindrops. For a height interval of $975-1425 \mathrm{~m}$ a relationship, $Z=215 R^{1.30}$, was obtained while $Z=240 R^{1.3}$ was found at a level of $525-975 \mathrm{~m}$. Atlas and Chmela (1957) calculated that coalescence should increase both the coefficient and the exponent. In both of these cases the effect of coalescence between raindrops is considered to be of little importance below the cloud base.

The effect of evaporation, under some conditions, can produce large differences in the $Z-R$ relationship. Data from Hardy (1962) in Flagstaff, Ariz., and from Foote (1966) in Tucson, Ariz., as well as recent data of the Illinois State Water Survey, indicate that the evaporation effects in the dry hot climate of Arizona produce the high coefficients noted in Table 2.

\section{g. Storm amounts by various equations}

One means of demonstrating the importance of using different relationships under different conditions is to evaluate the same storm using different equations. For this study 10 storm periods were selected at random, subject to having at least $45 \mathrm{~min}$ of data as well as different synoptic and rain type situations. For these storms a $Z$ value for each minute was available, and a $Z-R$ relationship was used to calculate a rainfall rate for each minute. The total storm rainfall was then calculated. This was performed for the synoptic relationship, the rain type relationship, and the standard Marshall-Palmer relationship.

It should be realized that this procedure is not strictly valid since the storms chosen for analysis were storms whose data have been incorporated in the determination of the relationships. It would be much better if data which were independent of the analysis could have been obtained. Table 8 shows the result of this analysis for the 10 storms at three different locations. Italicized values of computed rainfall represent those which compared best with the actual amount.

For the Miami storms, the synoptic equation appears to be better than either the rain type or the MarshallPalmer, although the differences with rain type are not large. The warm front storm was the poorest fit by the synoptic relationship. In this case the error amounts to a $21 \%$ overestimate of the amount of rainfall. The standard error of estimate for this synoptic relationship is 0.145 , which is one of the lower values from the Florida data. A standard error of estimate of this size would indicate that the calculated rate is from $29 \%$ lower to $40 \%$ higher than the true rate $68 \%$ of the time. Fortunately, the scatter around the relationships (measured by the standard error of estimate) is unduly 
pessimistic in determining the error in total rainfall amounts from storms of relatively long durations.

On the other hand, the standard error of estimate provides a more reliable index by which to determine which type of relationship is best. Again using the Florida data, the average standard error of estimate is 0.164 for the synoptic equations and 0.187 for the rain type equation, thus indicating the superiority in general of the synoptic sorting. As is evidenced in the small sample of four storms, the synoptic equation is better than the rain-type equations.

Oregon data has an average standard error of estimate of 0.119 for the rain type and 0.134 for the synoptic type. At this location the rain type appears to be a better predictor of the $Z-R$ relationships than the synoptic conditions. Again, even with the small sample of three storms, this appears to be the case.

In the Marshall Islands, both the synoptic equation and the rain type show a better correspondence between rainfall amounts than the Marshall-Palmer equation. Amounts are $30-40 \%$ larger than those from the Marshall-Palmer equation and nearly equal to the actual rainfall.

\section{Summary and conclusions}

The five-fold differences in $Z$ - $R$ reported by the many investigators appear to be attributable to the nature of the rain at different climatic locations. Although all of the relationships that have been found do undoubtedly contain some experimental error, the size of this error is so much less than the magnitude of the differences in relationships that it must be concluded that rainfall is widely variant with location and from day to day at a given location.

The accuracy of the relationships when considered on a point-by-point basis is not very good. Thus, a standard error of the logarithm of 0.180 indicates that, for any one measurement of $Z$, the indicated rainfall rate will lie between 0.66 to 1.52 times the true rate $68 \%$ of the time. Fortunately, the instantaneous rainfall rate is usually not as important as the amount of rainfall at the end of the rain. When an average is taken over a number of observations, these accuracy limits are materially reduced.

The extensive evaluation of worldwide drop size measurements suggests that one would improve his radar measurement of precipitation through knowledge of the climatic differences in raindrop size spectra. Once this has been established, use of the synoptic weather conditions would allow further improvement, providing the radar is sufficiently accurate to warrant further stratification.

In addition, the nature of the precipitating volume should be considered. For convective storms where the reflectivity is fairly constant over a large height interval, the major uncertainties are probably those related to the measurement of the radar signal and to the $Z-R$ relation. For more widespread rain, however, large uncertainties may be introduced because of changes in the precipitation between the level of the radar beam and the ground.

While discussing the variance or scatter of the relationships, the accuracy permitted by present radar techniques should also be considered. Theory indicates that the appropriate radar parameter which should be measured to determine rainfall rate is the average return power. This average return power has frequently been measured by photographing a PPI scope for a number of radar revolutions while the sensitivity of the radar receiver is changed. This technique is commonly called step-gain procedure. The accuracy of step-gain pictures has been estimated to be as much as $\pm 5 \mathrm{db}$. Under ideal conditions of careful calibration with a noise source, the authors feel that the accuracy may be somewhat better $( \pm 3 \mathrm{db})$, but even so this uncertainty is so great that its use will introduce uncertainty of a magnitude comparable with the uncertainty due to the $Z-R$ relationship. Modern techniques of radar signal processing in either analog or digital integrators allow a reduction in this radar measurement error to about $\pm 1.5 \mathrm{db}$. To effectively utilize this accuracy it becomes necessary to use different $Z-R$ relationships for changing synoptic conditions.

Acknoreledgments Credit is due Arthur Sims and Robert Cataneo who have performed numerous analyses which were pertinent in preparation of this manuscript. Work on this manuscript has been partially supported by the U. S. Army under contract DA 28-043 AMC 02071(E). All of the drop camera data were collected through support from the U. S. Army Electronics Command.

\section{RENERENCES}

Aoyagi, J., 1964: Areal rainfall amounts obtained by a $3.2-\mathrm{cm}$ radar and a raingage network. Proc. 11th Wea. Radar Conf., Boulder, Colo., 116-119.

Atlas, D., and A. C. Chmela, 1957: Physical-synoptic variations of raindrop size parameters. Proc. 6th Wea. Radar Conf., Cambridge, Mass. 21-30.

Austin, P. M., 1964: Radiar measurements of precipitation rate. Proc. 1th Wea. Radar Conf., Boulder, Colo., 120-125.

-_- and E. L. Williams, 1951: Comparison of radar signal intensity with precipitation rate. Dept. of Meteoroology, Mass. Institute of Technology, Wea. Res. Tech. Rept. No. 14,43 pp.

Berjuljev, G. P., et al., 1966: The results of radar measurements of areal rainfall in Valday. Proc. 12t/l Conf. on Radar Meteor., Norman, Okla., 220-221.

Blanchard, D. C., 1953: Raindrop size-distribution in Hawaiian rains. J. Meteor., 10, 457-473.

Caton, P. G. F., 1964: A study of raindrop size distributions in the free atmosphere. Proc. 11th Wea. Radar Conf., Boulder, Colo., 136-141.

Diem, M., 1966: Rains in the arctic, temperate, and tropical zone. Sci. Rept., Meteorologisches Institut Technische Hochschule, Karlsruhe, Contract DA-91-591-EUC-3634, $93 \mathrm{pp}$. 
Dimaksian, A. M., N. V. Zotimov and N. A. Zykov, 1962: Measurement of the intensity of rainfall by radar method. Tr. Gos. Gidrolog. Inst., No. 87, 469-488. (See complete translation in "Soviet Hydrology: Selected Papers," 5, 1962).

$\ldots$, and —_, 1965: Results of radar measurements of liquid precipitation. Tr. Gos. Gidrolog. Inst., No. 130, 530-537. (See complete translation in "Soviet Hydrology : Selected Papers," 6, 1965).

Doherty, L. H., 1963: The scattering coefficient of rain from forward scatter measurements. Proc. 10th Wea. Radar Conf., Washington, D. C., 171-175.

Dumoulin, G., and A. Gogolombles, 1966: A comparison of radar values of precipitation intensities and rainfall rate from a raingage. Proc. 12 th Conf. on Radar Meteor., Norman, Okla., 190-197.

Foote, G. B., 1966: A $Z-R$ relation for mountain thunderstorms. J. Appl. Meteor., 2, 229-231.

Fujiwara, M., 1967: Preliminary report on Hawaii rain mechanism. Tellhes, 3, 392-402.

Gunn, R., and G. D. Kinzer, 1949: The terminal velocity of fall for water droplets in stagnant air. J. Meteor., 6, 243-248.

Hardy, K. R., 1962: A study of raindrop size distributions and their variations with height. Sci. Rept. No. 1, Univ. of Michigan, Contract AF 19(628)-281, 174 pp.

Hudson, H. E., Jr., G. E. Stout and F. A. Huff, 1952: Studies of thunderstorm rainfall with dense raingage networks and radar. Rept. of Investigation 13, Ill. State Water Survey, $30 \mathrm{pp}$.

Imai, I., 1960: Raindrop size distributions and $Z-R$ relationships. Proc. 8th Wea. Radar Conf., San Francisco, Calif., 211-218.

Marshall, J. S., R. C. Langille and W. McK. Palmer, 1947: Measurement of rainfall by radar. J. Meteor., 4, 186-192.

Mueller, E. A., and A. L. Sims, 1966a: The influence of sampling. volume on raindrop size spectra. Proc. $12 \mathrm{lh}$ Conf. on Radar Meteor., Norman, Okla., 135-141.

$\ldots$, and - 1966b: Investigation of the quantitative determination of point and areal precipitation by radar echo measurements. Ill. State Water Survey, Final Rept., Contract DA 28-043 AMC 00032(E), $110 \mathrm{pp}$.

Sims, A. L., 1964: Case studies of the areal variation in raindrop size distribution. Proc. 11th Wea. Radar Conf., Boulder, Colo., 162-165.

Wilson, J. W., 1963: Storm-to-storm variability in the radar reflectivity rainfall rate relationship. Proc. 12th Conf. on Radar Meteor, Norman, Okla., 229-233. 